\title{
Italy pursues cuts in manned space efforts
}

Rome. The Italian Space Agency (ASI) is planning to seek reductions in its various commitments to the space programmes of the European Space Agency (ESA) in an effort to draw its books into balance its books.

Italy's move will add to ESA's troubles in getting agreement from its member states on its proposed ECU3.9-billion (US\$4.8billion) budget for the next eight-year (1995-2003) manned space flight programme, which is already under attack from both Germany and France.

European manned space efforts have been losing political support in the 1990 s as recession has hit ESA's member states. Italy in particular has faced severe difficulties, while ASI itself has been troubled by administrative and financial problems since it was set up in 1988.

In the early 1980 s, Italy decided to become a major force in European space. But by the 1990 s it was no longer prepared to back up this political will with the necessary financial commitment. ASI's budget, for example, has been frozen for the last three years, and by last summer the agency had already run up an overall deficit of IL500 billion (US\$310 million).

Most of the ASI budget is used to support Italy's participation in ESA programmes. Even so, in 1993, it was able to cover only two-thirds of its ESA bills, and early last year, ESA agreed to take out a IL189-billion loan on ASI's behalf, to be paid back by the Italian government before the end of 1996.

Meanwhile, research scientists in Italy were protesting that the agency was diverting funds that they claimed were intended for the national basic research programme to support its ESA commitments (see $\mathrm{Na}$ ture 356, 647; 199).

Two years ago, Umberto Colombo, research minister in the interim government, installed a commissioner to try to sort out its problems. By last summer, the agency was back on its administrative feet, with a new president and a new board. In particular, it was once more able to distribute grant money to research scientists, for example.

The new director general, Mario Calamia, has since been renegotiating international commitments, particularly those with ESA. The heaviest commitments, which include data relay satellite programmes and early developmental parts of manned space flight programmes, run until 1996. Calamia says that Italy will not backtrack from these, but will instead try to delay payments, possibly by securing another bank loan through ESA.

Most important, he says, is to ensure that post-1997 commitments are reduced. "We want to extend the timeframe of some commitments and we will certainly cancel others", he says. He will not be drawn on where the axe might fall, but it will almost certainly involve its obligations to the ESA manned space flight programme, to which Italy committed itself heavily at the ESA ministerial meeting in Grenada in 1992.

The original manned space programme, promoted heavily by Italy in collaboration with Germany in the mid-1980s, was intended to guarantee Europe autonomous access to space, as well as the opportunity to participate significantly in the US international space programme.

It included a small space laboratory known as the Man-Tended Free Flyer (MTFF), a space plane called Hermes and an attached pressurized module (APM), part of the so-called Columbus programme, which would attach either onto the MTFF space station or the planned international

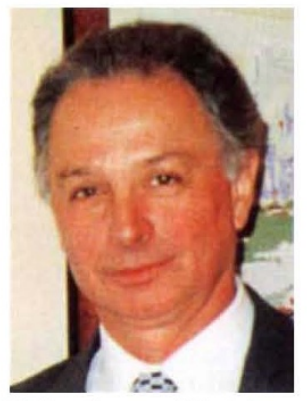

Calamia: seeking to balance the books. space station.

But, given Europe's changed economic circumstances, the MTFF and the Hermes programme were formally abandoned at the Grenada meeting. The Colombus programme was given the green light. But in the last two years the APM has been scaled down to a much smaller unit called the Columbus Orbital Facility (COF) which will dock with the international space station, and which should be around half the price.

Last month, ESA put forward a proposed ECU3.9-billion manned space flight programme, ECU1 billion of which would be earmarked for COF. The proposed budget has to be approved at the next ministerial meeting in November this year. As a result, Italy, which enthusiastically agreed to fund 31 per cent of the Columbus programme in million, between 1995 and 2003

Italy might try to withdraw from the programme altogether. But that would put its partners under severe pressure. Italy is more likely to seek a smaller share of the programme, and ask that it be extended over a longer period to reduce annual cost.

The second option in particular could win support from Germany and France, Grenada, could be asked to pay over ECU300

ESA's largest contributors. They have already responded to ESA's proposal by saying that they will not support a figure higher than ECU2 billion for the eight-year programme.

Calamia says he does not intend to join Britain's fight to reduce the costs of ESA's mandatory space science programmes (see Nature 372, 712; 1994). "The money involved [IL97 billion in 1994] is very small compared with our commitments on optional programmes [IL419 billion]", he says.

In addition to trying to reduce ESA payouts, Calamia is exploring possible ways of reducing ASI's space commitments under bilateral agreements with the United States. The heaviest of these is its agreement to provide three Mini-Pressurized Logistic Modules (MPLMs) to carry cargo up to the space station, at a cost of US\$500 million. The launch of the first MPLM is due in December 1997.

But Calamia says that ASI will not curb its spending on the controversial X-ray satellite SAX. This is a national programme that has suffered excessive price increases and extended delays, which, many scientists argue, have reduced its scientific value so much that it is no longer worthwhile (see Nature 366, 101; 1993).

ASI is not being helped in solving its financial problems by continual upheaval in its administration. Former research minister Stefano Podestá, who succeeded Colombo last summer, twice tried unsuccessfully to force through emergency legislation dissolving the agency's administration once more and installing an amminstratore unico, a 'single administrator', with full control of all ASI business (see Nature 372, 719; 1994).

Podestá finally succeeded in pushing through a decree during the turmoil of the last days of his government last month. But while the decree immediately removed the administration, no amministratore unico was appointed, and the agency was left head-less for a month.

Last week parliament rescinded the decree, and the former administrative bodies have been reestablished. Parliament will now consider a bill with the same aims as the decree - namely to install a single administrator with broad powers - but which, unlike Podestá's bill, will be fully debated.

Alison Abbott

\section{Chile court backs locals in telescope row}

Munich. Chile's supreme court last week ruled in favour of the Latorre family which claims to own the land on which the European Southern Observatory (ESO) is currently building its DM463-million (US\$300million) Very Large Telescope (VLT).

As a result, work on the site, whose ownership has been the subject of an intense and protracted legal battle (see
Nature 368,676 ; and 370,$494 ; 1994)$, is being required to stop until the claim is resolved.

But the ESO has already invested heavily in construction work at the site on the top of Mount Paranal in northern Chile, and is continuing with the building work as it has not received any formal instructions from the government to stop. A. A. 